\title{
CORRIGENDUM
}

\section{Galvanotactic control of collective cell migration in epithelial monolayers}

Daniel J. Cohen, W. James Nelson and Michel M. Maharbiz

Nature Materials 13, 409-417 (2014); published online 9 March 2014; corrected after print 21 March 2014.

In the version of this Article originally published, in Figs $4 \mathrm{a}, \mathrm{e}, 5 \mathrm{~b}, \mathrm{c}$ and $6 \mathrm{a}$, the units for velocity should have read ' $\mu \mathrm{m} \mathrm{h}^{-1}$ '. This error has now been corrected in the online versions of the Article. 